\title{
IL-6 in Inflammation, Immunity, and Disease
}

\author{
Toshio Tanaka $^{1,2}$, Masashi Narazaki ${ }^{3}$, and Tadamitsu Kishimoto ${ }^{4}$ \\ ${ }^{1}$ Department of Clinical Application of Biologics, Osaka University Graduate School of Medicine, Osaka \\ University, Osaka 565-0871, Japan \\ ${ }^{2}$ Department of Immunopathology, World Premier International Immunology Frontier Research Center, Osaka \\ University, Osaka 565-0871, Japan \\ ${ }^{3}$ Department of Respiratory Medicine, Allergy and Rheumatic Diseases, Osaka University Graduate School \\ of Medicine, Osaka University, Osaka 565-0871, Japan \\ ${ }^{4}$ Laboratory of Immune Regulation, World Premier International Immunology Frontier Research Center, Osaka \\ University, Osaka 565-0871, Japan \\ Correspondence: kishimoto@ifrec.osaka-u.ac.jp
}

Interleukin 6 (IL-6), promptly and transiently produced in response to infections and tissue injuries, contributes to host defense through the stimulation of acute phase responses, hematopoiesis, and immune reactions. Although its expression is strictly controlled by transcriptional and posttranscriptional mechanisms, dysregulated continual synthesis of IL-6 plays a pathological effect on chronic inflammation and autoimmunity. For this reason, tocilizumab, a humanized anti-IL-6 receptor antibody was developed. Various clinical trials have since shown the exceptional efficacy of tocilizumab, which resulted in its approval for the treatment of rheumatoid arthritis and juvenile idiopathic arthritis. Moreover, tocilizumab is expected to be effective for other intractable immune-mediated diseases. In this context, the mechanism for the continual synthesis of IL-6 needs to be elucidated to facilitate the development of more specific therapeutic approaches and analysis of the pathogenesis of specific diseases.

L-6 is a soluble mediator with a pleiotropic effect on inflammation, immune response, and hematopoiesis. At first, distinct functions of IL- 6 were studied and given distinct names based on their biological activity. For example, the name B-cell stimulatory factor 2 (BSF-2) was based on the ability to induce differentiation of activated B cells into antibody (Ab)-producing cells (Kishimoto 1985), the name hepatocyte-stimulating factor (HSF) on the effect of acute phase protein synthesis on hepatocytes, the name hybridoma growth factor (HGF) on the enhancement of growth of fusion cells between plasma cells and myeloma cells, or the name interferon (IFN)- $\beta 2$ owing to its IFN antiviral activity. When the BSF-2 cDNA was successfully cloned in 1986 (Hirano et al. 1986), however, it was found that the molecules with different names studied by various groups were in fact identical, resulting in the single name IL6 (Kishimoto 1989). Human IL-6 is made up of 212 amino acids, including a 28-amino-acid

Editor: Ruslan M. Medzhitov

Additional Perspectives on Innate Immunity and Inflammation available at www.cshperspectives.org

Copyright (C) 2014 Cold Spring Harbor Laboratory Press; all rights reserved; doi: 10.1101/cshperspect.a016295

Cite this article as Cold Spring Harb Perspect Biol 2014;6:a016295 
T. Tanaka et al.

signal peptide, and its gene has been mapped to chromosome $7 \mathrm{p} 21$. Although the core protein is $\sim 20 \mathrm{kDa}$, glycosylation accounts for the size of $21-26 \mathrm{kDa}$ of natural IL-6.

\section{BIOLOGICAL EFFECT OF IL-6 ON INFLAMMATION AND IMMUNITY}

After IL-6 is synthesized in a local lesion in the initial stage of inflammation, it moves to the liver through the bloodstream, followed by the rapid induction of an extensive range of acute phase proteins such as C-reactive protein (CRP), serum amyloid A (SAA), fibrinogen, haptoglobin, and $\alpha 1$-antichymotrypsin (Fig. 1) (Heinrich et al. 1990). On the other hand, IL-6 reduces the production of fibronectin, albumin, and transferrin. These biological effects on hepatocytes were at first studied as belonging to HSF. When high-level concentrations of SAA persist for a long time, it leads to a serious complication of several chronic inflammatory diseases through the generation of amyloid A amyloidosis (Gillmore et al. 2001). This results in amyloid fibril deposition, which causes progressive deterioration in various organs. IL- 6 is also involved in the regulation of serum iron and zinc levels via control of their transporters. As for serum iron, IL-6 induces hepcidin production, which blocks the action of iron transporter ferroportin 1 on gut and, thus, reduces serum iron levels (Nemeth et al. 2004). This means that the IL-6-hepcidin axis is responsible for hypoferremia and anemia associated with chronic inflammation. IL-6 also enhances zinc importer ZIP14 expression on hepatocytes and so induces hypozincemia seen in inflammation (Liuzzi et al. 2005). When IL-6 reaches the bone marrow, it promotes megakaryocyte maturation, thus leading to the release of platelets (Ishibashi et al. 1989). These changes in acute phase protein levels and red blood cell and platelet counts are used for the evaluation of inflammatory severity in routine clinical laboratory examinations.

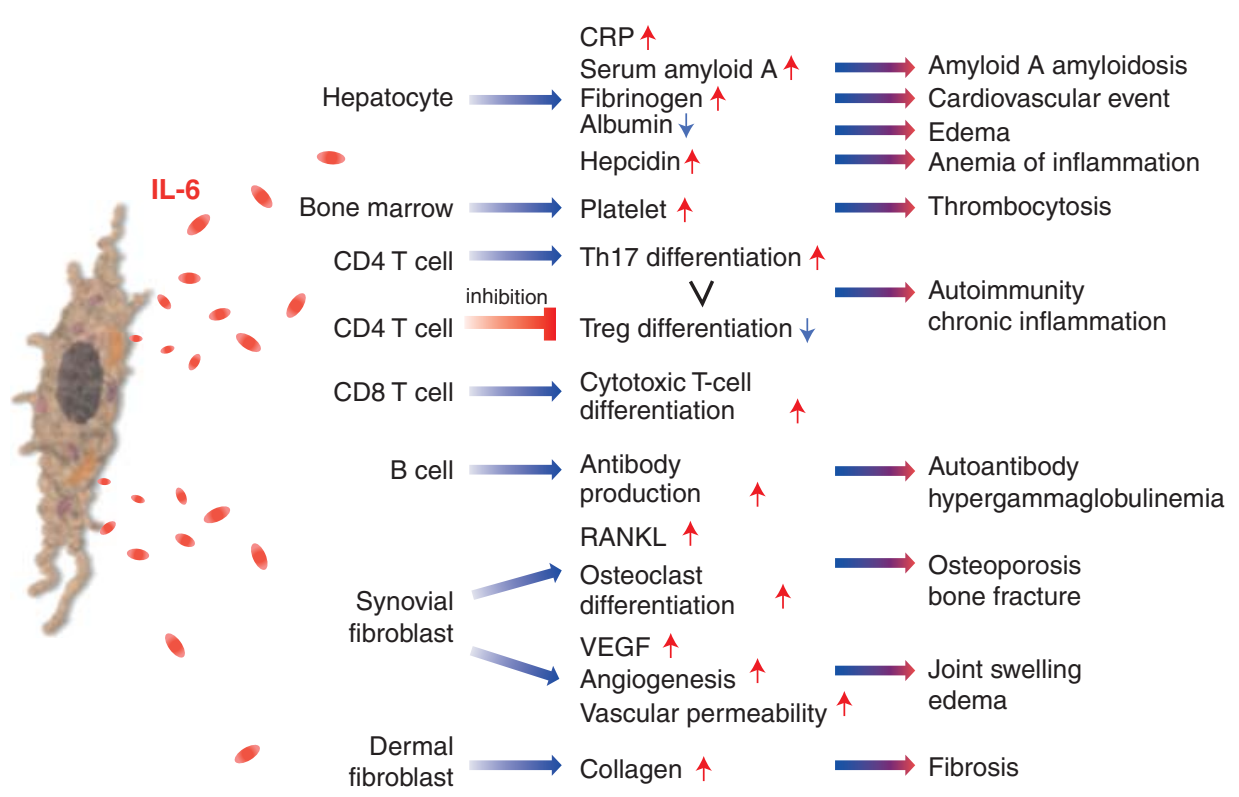

Figure 1. IL-6 in inflammation, immunity, and disease. IL-6 is a cytokine featuring pleiotropic activity; it induces synthesis of acute phase proteins such as CRP, serum amyloid A, fibrinogen, and hepcidin in hepatocytes, whereas it inhibits production of albumin. IL- 6 also plays an important role on acquired immune response by stimulation of antibody production and of effector T-cell development. Moreover, IL- 6 can promote differentiation or proliferation of several nonimmune cells. Because of the pleiotropic activity, dysregulated continual production of IL-6 leads to the onset or development of various diseases. Treg, regulatory T cell; RANKL, receptor activator of nuclear factor $\kappa \mathrm{B}(\mathrm{NF}-\mathrm{\kappa B})$ ligand; VEGF, vascular endothelial growth factor. 
Furthermore, IL-6 promotes specific differentiation of naïve $\mathrm{CD} 4^{+} \mathrm{T}$ cells, thus performing an important function in the linking of innate to acquired immune response. It has been shown that IL-6, in combination with transforming growth factor (TGF)- $\beta$, is indispensable for Th17 differentiation from naïve $\mathrm{CD} 4^{+} \mathrm{T}$ cells (Korn et al. 2009), but that IL-6 also inhibits TGF- $\beta$-induced Treg differentiation (Bettelli et al. 2006). Up-regulation of the Th17/Treg balance is considered to be responsible for the disruption of immunological tolerance, and is thus pathologically involved in the development of autoimmune and chronic inflammatory diseases (Kimura and Kishimoto 2010). It has been further shown that IL-6 also promotes T-follicular helper-cell differentiation as well as production of IL-21 (Ma et al. 2012), which regulates immunoglobulin (Ig) synthesis and IgG4 production in particular. IL-6 also induces the differentiation of $\mathrm{CD}^{+} \mathrm{T}$ cells into cytotoxic T cells (Okada et al. 1988). Under one of its previous names, BSF-2, IL-6 was found to be able to induce the differentiation of activated $\mathrm{B}$ cells into $\mathrm{Ab}$-producing plasma cells, so that continuous oversynthesis of IL- 6 results in hypergammaglobulinemia and autoantibody production.

IL-6 exerts various effects other than those on hepatocytes and lymphocytes and these are frequently detected in chronic inflammatory diseases (Kishimoto 1989; Hirano et al. 1990; Akira et al. 1993). One of these effects is that, when IL- 6 is generated in bone marrow stromal cells, it stimulates the RANKL (Hashizume et al. 2008), which is indispensable for the differentiation and activation of osteoclasts (Kotake et al. 1996), and this leads to bone resorption and osteoporosis (Poli et al. 1994). IL-6 also induces excess production of VEGF, leading to enhanced angiogenesis and increased vascular permeability, which are pathological features of inflammatory lesions and are seen in, for example, synovial tissues of rheumatoid arthritis (RA) or edema of remitting seronegative symmetrical synovitis with pitting edema (RS3PE) syndrome (Nakahara et al. 2003; Hashizume et al. 2009). Finally, it has been reported that IL-6 aids keratinocyte proliferation (Grossman et al. 1989) or the generation of collagen in dermal fibroblasts that may account for changes in the skin of patients with systemic sclerosis (Duncan and Berman 1991).

\section{REGULATION OF IL-6 SYNTHESIS}

IL-6 functions as a mediator for notification of the occurrence of some emergent event. IL- 6 is generated in an infectious lesion and sends out a warning signal to the entire body. The signature of exogenous pathogens, known as pathogenassociated molecular patterns, is recognized in the infected lesion by pathogen-recognition receptors (PRRs) of immune cells such as monocytes and macrophages (Kumar et al.2011). These PRRs comprise Toll-like receptors (TLRs), retinoic acid-inducible gene-1-like receptors, nucleotide-binding oligomerization domain-like receptors, and DNA receptors. They stimulate a range of signaling pathways including NF- $\kappa \mathrm{B}$, and enhance the transcription of the mRNA of inflammatory cytokines such as IL-6, tumor necrosis factor (TNF) $-\alpha$, and IL- $1 \beta$. TNF- $\alpha$ and IL-1 $\beta$ also activate transcription factors to produce IL-6.

IL-6 also issues a warning signal in the event of tissue damage. Damage-associated molecular patterns (DAMPs), which are released from damaged or dying cells in noninfectious inflammations such as burn or trauma, directly or indirectly promote inflammation. During sterile surgical operations, an increase in serum IL6 levels precedes elevation of body temperature and serum acute phase protein concentration (Nishimoto et al. 1989). DAMPs from injured cells contain a variety of molecules such as mitochondrial (mt) DNA, high mobility group box 1 (HMGB1), and S100 proteins (Bianchi 2007). Serum mtDNA levels in trauma patients are thousands of times higher than in controls and this elevation leads to TLR9 stimulation and NF- $\kappa$ B activation (Zhang et al. 2010), whereas binding of HMGB1 to TLR2, TLR4, and the receptor of advanced glycation end products (RAGE) can promote inflammation. The S100 family of proteins comprises more than 25 members, some of which also interact with RAGE to evoke sterile inflammation (Sims et al. 2010). 
T. Tanaka et al.

In addition to immune-mediated cells, mesenchymal cells, endothelial cells, fibroblasts, and many other cells are involved in the production of IL-6 in response to various stimuli (Akira et al. 1993). The fact that IL-6 issues a warning signal to indicate occurrence of an emergency accounts for the strict regulation of IL-6 synthesis both gene transcriptionally and posttranscriptionally. A number of transcription factors have been shown to regulate the IL-6 gene transcription (Fig. 2). The functional cis-regulatory elements in the human IL- 6 gene $5^{\prime}$ flanking region are found binding sites for NF- $\mathrm{KB}$, specificity protein 1 (SP1), nuclear factor IL-6 (NF-IL-6) (also known as CAAT/enhancerbinding protein $\beta$ ), activator protein 1 (AP-1), and interferon regulatory factor 1 (Libermann and Baltimore 1990; Akira and Kishimoto 1992; Matsusaka et al. 1993). Activation of cis-regulatory elements by stimulation with IL-1, TNF, TLR-mediated signal, and forskolin lead to activation of the IL- 6 promoter.

A polymorphism at position -174 of the IL- 6 promoter region is reportedly associated with systemic onset juvenile idiopathic arthritis (Fishman et al. 1998) and susceptibility to RA in Europeans (Lee et al. 2012). Stimulation with lipopolysaccharide (LPS) and IL-1 did not evoke any response in a reporter assay using $-174 \mathrm{C}$ construct. A -174 G construct, on the other hand, was found to promote transcription of the reporter gene, suggesting that a genetic back-

\begin{tabular}{|l|l|l|}
\cline { 2 - 3 } \multicolumn{1}{c|}{} & \multicolumn{1}{c|}{ Protein } & \multicolumn{1}{c|}{ MicroRNA } \\
\hline Promotion & NF-kB, SP-1 & \\
& NF-IL-6, AP-1 & \\
& IRF1, Tax & \\
& TAT, HBVX & \\
& Mutant p53 & \\
\hline Repression & Ahr,GR, ER & miR-155 (targeting NF-IL-6) \\
& p53, Rb & miR-146a/b (targeting IRAK1) \\
& PPAR $\alpha$ & miR-223 (targeting STAT3) \\
\hline \multicolumn{3}{|c|}{ Transcriptional regulation }
\end{tabular}

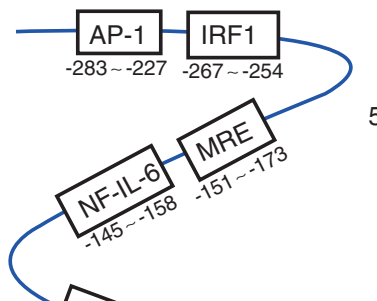

\begin{tabular}{|l|l|l|}
\cline { 2 - 3 } \multicolumn{1}{c|}{} & Protein & MicroRNA \\
\hline Stabilization & Arid5a & \\
& P38 $\alpha$ & \\
& ORF57 & \\
\hline Degradation & Regnase-1 & miR-365 \\
& TTP & miR-608 \\
& BRF1 & \\
& BRF2 & \\
\hline
\end{tabular}

Posttranscriptional regulation 5'-AUUUUAAUUAUUUUUAUUUAUUGAUAAUUUAAAUAAGU AAA CUUUAAGUUAAUUUAUGAUUGAUAUUUAUUAUUUUUA-3'

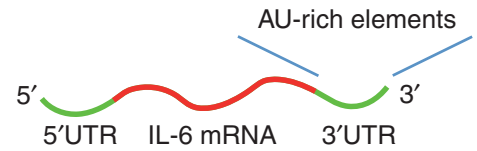

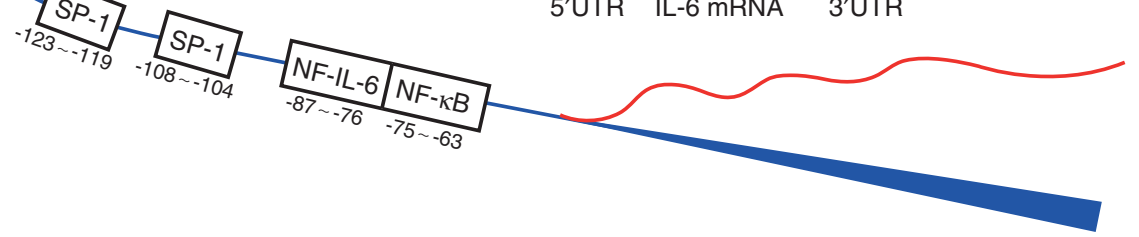

Figure 2. Transcriptional and posttranscriptional regulation of IL-6 gene. The expression and degradation of IL6 mRNA is regulated transcriptionally and posttranscriptionally by several proteins and microRNAs. Activation of these proteins and microRNAs determines the fate of IL-6 mRNA. NF-IL-6, nuclear factor of IL-6; Tax, transactivator protein; TAT, transactivator of the transcription; HBVX, hepatitis B virus X protein; Ahr, aryl hydrocarbon receptor; GR, glucocorticoid receptor; ER, estrogen receptor; Rb, retinoblastoma; PPAR $\alpha$, peroxisome proliferator-activated receptor $\alpha$; miR, microRNA; IRAK1, IL-1 receptor-associated kinase 1; STAT3, signal transducer and activator of transcription 3; ORF, open reading frame; TTP, tristetraprolin; BRF1, butyrate response factor 1 . 
ground of excess IL-6 production constitutes a risk factor for juvenile idiopathic arthritis and RA.

An interesting finding is that some viral products enhance the DNA-binding activity of NF- $\kappa B$ and NF-IL-6, resulting in an increase in IL-6 mRNA transcription. An instance of this phenomenon is that interaction with NF- $\mathrm{KB}$ of the Tax derived from the human Tlymphotropic virus 1 enhances IL-6 production (Ballard et al. 1988; Leung and Nabel 1988). Another example is the enhancement of both NF- $\kappa$ B and NF-IL-6 DNA-binding activity by the transactivator of the TAT protein of the human immunodeficiency virus 1 (Scala et al. 1994; Ambrosino et al. 1997). Moreover, it has been shown that DNA binding of NF-IL- 6 can be enhanced by the human hepatitis B virus $\mathrm{X}$ protein (Mahe et al. 1991; Ohno et al. 1999).

On the other hand, some transcription factors suppress IL-6 expression. Peroxisome proliferator-activated receptors (PPARs) are ligand-activated transcription factors consisting of three subtypes: $\alpha, \beta$, and $\gamma$. Among three PPARs, fibrates-activated PPAR $\alpha$ interacts with c-Jun and p 65 NF- $\kappa$ B subunits, which negatively regulate IL-6 transcription (Delerive et al. 1999). In addition, some hormone receptors have been identified as repressors of IL- 6 expression. The increase in serum IL-6 after menopause or ovarectomy is reportedly associated with suppression of IL-6 expression by estrogen receptors (Jilka et al. 1992), whereas activation of the glucocorticoid receptor can repress IL-6 expression, and this is thought to be one of mechanisms responsible for the anti-inflammatory effects of corticosteroids (Ray and Prefontaine 1994). It has further been shown that retinoblastoma protein and p53 repress the IL- 6 gene promoter, whereas it is up-regulated by mutant p53 (Santhanam et al. 1991).

In addition, some microRNAs directly or indirectly regulate transcription activity. Interaction of microRNA-155 with the $3^{\prime}$ untranslated regions (UTR) of NF-IL-6 results in suppression of NF-IL-6 expression (He et al. 2009), whereas microRNA-146a/b and -223 indirectly suppress transcription of IL-6 by respectively targeting IL-1 receptor-associated kinase
1 and STAT3 (Chen et al. 2012; Zilahi et al. 2012).

\section{PRODUCTION AND FUNCTION OF IL-6 AND ARYL HYDROCARBON RECEPTOR}

Aryl hydrocarbon receptor (Ahr) not only affects IL-6 transcription, but also regulates innate and acquired immune response. Ahr, also known as the dioxin receptor, is a ligand-activated transcription factor that belongs to the basic helix-loop-helix PER-ARNT-SIM family (Burbach et al. 1992; Ema et al. 1992). Ahr is present in the cytoplasm, where it forms a complex with Ahr-interacting protein (Bell and Poland 2000). On binding with a ligand, Ahr moves to the nucleus and dimerizes with the Ahr nuclear translocator (Arnt). Within the nucleus, the Ahr/Arnt heterodimer then binds to the xenobiotic response element (XRE), which leads to various toxicological effects (Fujii-Kuriyama et al. 1994; Dragan and Schrenk 2000; Ohtake et al. 2003; Puga et al. 2005). Although the physiological ligands for Ahr are not well known, indoleamine 2,3-dioxygenase (IDO), which catalyzes tryptophan into kynurenine, is induced by Ahr signaling and kynurenine is one of the ligands of Ahr (Vogel et al. 2008; Jux et al. 2009).

An animal model of RA was used to show the essential role of Ahr in the induction of Th17 cells and Th17-dependent collagen-induced arthritis (CIA) (Kimura et al. 2008; Nakahama et al. 2011). Stimulation of naïve T cells with IL-6 plus TGF- $\beta$ (Th17 cell-inducing condition) induced Ahr expression and deletion of the Ahr gene nullified the induction of Th17 cells.

Ahr interacted with and inhibited the activities of STAT1 or STAT5, which mediate the anti-inflammatory signals of IL-27 and IFN$\gamma$, or IL-2, respectively (Harrington et al. 2005; Stumhofer et al. 2006; Laurence et al. 2007; Kimura et al. 2008), thus suppressing the inhibitory signals for the induction of Th17 cells. Retinoid-related orphan receptors (ROR) $\gamma$ and $\alpha$, which are activated by STAT3, are essential transcription factors for Th17-cell induction (Ivanov et al. 2006; Yang et al. 2008) and Ahr was 
T. Tanaka et al.

found not to affect the ROR- $\gamma$ and $-\alpha$ expression. In the Ahr gene-deficient mice, no arthritis developed in CIA. Moreover, with T-cell-specific deletion of the Ahr gene, no development of CIAwas observed (Nakahama et al. 2011). These results clearly show that CIA is a T-cell-dependent disease and the presence of Ahr is essential for its development. In these Ahr-deficient mice, the number of Th17 cells decreased and that of Th1 cells increased but no significant changes were observed in Foxp3-expressing Treg cells.

Ahr also regulates Th17-cell induction through regulation of microRNAs. In our study, Ahr-induced microRNA-132/212 cluster under Th17 cell-inducing conditions and transfection of microRNA-212 into naïve $\mathrm{T}$ cells under these circumstances augmented the expression of IL17-related genes such as IL-17A, IL-22, and IL23R (Nakahama et al. 2013). One of the target genes of this microRNA is B-cell lymphoma 6 , which is known as an inhibitor of Th17-cell induction (Yu et al. 2009). All of these findings show that Ahr accelerates inflammation through the enhancement of Th17-cell induction by several mechanisms.

Interestingly, Ahr showed a negative regulatory effect on peritoneal macrophages and bone marrow-derived dendritic cells (BMDC) (Nguyen et al. 2010). In the absence of Ahr, LPS-induced production of inflammatory $\mathrm{cy}$ tokines such as IL-6, TNF, and IL-12 showed major increases in macrophages, indicating that Ahr negatively regulates inflammatory cytokine production. Ahr interacts with STAT1 and NF- $\kappa \mathrm{B}$ and the resultant complex of Ahr/ STAT1 and NF- $\kappa$ B leads to inhibition of the promoter activity of IL-6 and other inflammatory cytokines (Kimura et al. 2009). In BMDC, Ahr is required for the activation of IDO leading to kynurenine production because the deletion of Ahr in BMDC leads to loss of IL-10 and kynurenine production. Coculture of naïve $\mathrm{T}$ cells with Ahr-deficient BMDC in the presence of LPS resulted in reduction of Treg-cell induction, whereas addition of kynurenine rescued the induction of Treg cells by BMDC (Nguyen et al. 2010). These findings indicate that Ahr is required for the regulatory BMDC cells through the induction of IDO.

\section{STABILIZATION AND DEGRADATION OF IL-6 MRNA (ARID5A AND REGNASE-1)}

As for posttranscriptional regulation of cytokine expression, cytokine mRNA is controlled through both the $5^{\prime}$ and $3^{\prime}$ UTR (Chen and Shyu 1995; Anderson 2008). Initiation of mRNA translation is determined by the $5^{\prime} \mathrm{UTR}$, and the stability of mRNA by the $3^{\prime} U T R$. IL- 6 mRNA is regulated by modulation of AU-rich elements located in the $3^{\prime}$ UTR region, whereas a number of RNA-binding proteins and microRNAs bind to the $3^{\prime}$ UTRs and regulate the stability of IL-6 mRNA (Fig. 2). For example, IL-6 mRNA stabilization is promoted by mitogen-activated protein kinase (MAPK) p38 $\alpha$ via 3'UTRs of IL-6 (Zhao et al. 2008), and the stabilization of both viral and human IL-6 mRNA by the Kaposi's sarcoma-associated herpesvirus (KSHV) ORF-57 by competing with the binding of microRNA-1293 to the viral or of microRNA-608 to the human IL-6 mRNA (Kang et al. 2011). RNA-binding proteins, such as TTP and BRF1 and 2, on the other hand, promote IL-6 mRNA degradation (Palanisamy et al. 2012), whereas IL-6 mRNA levels are reduced by microRNAs such as microRNA365 and -608 through direct interaction with IL$63^{\prime}$ UTR (Kang et al. 2011; Xu et al. 2011).

It was recently found that a nuclease known as regulatory RNase-1 (regnase-1) (also known as Zc3h12a) plays a part in the destabilization of IL-6 mRNA, and that the relevant knockout mice spontaneously develop autoimmune diseases accompanied by splenomegaly and lymphadenopathy (Matsushita et al. 2009). The inhibitor of NF- $\mathrm{KB}$ (IкB) kinase (IKK) complex controls IL-6 mRNA stability by phosphorylating regnase-1 in response to IL-1R/TLR stimulation (Iwasaki et al. 2011). Phosphorylated regnase- 1 underwent ubiquitination and degradation. Regnase-1 re-expressed in IL-1R/TLRactivated cells was found to feature delayed kinetics, and regnase- 1 mRNA to be negatively regulated by regnase-1 itself via a stem-loop region present in the regnase- $13^{\prime} U T R$. These findings show that IKK complex phosphorylates not only $\mathrm{I \kappa} B \alpha$, activating transcription, but also regnase-1, releasing the brake on IL-6 mRNA ex- 
pression. Regnase- 1 also regulates the mRNAs of a set of genes, including c-Rel, Ox40, and IL-2 through cleavage of their $3^{\prime}$ UTRs in T cells. Tcell receptor engagement then leads to cleavage of regnase-1, which frees $\mathrm{T}$ cells from regnasemediated suppression, thus indicating that regnase- 1 may play a crucial role in T-cell activation (Uehata et al. 2013).

We have recently identified a novel RNAbinding protein, AT-rich interactive domaincontaining protein $5 \mathrm{a}$ (Arid5a), which binds to the $3^{\prime}$ UTR of IL- 6 mRNA, resulting in the selective stabilization of IL- 6 but not of TNF- $\alpha$ or IL-12 mRNA (Masuda et al. 2013). Arid5a expression was found to be enhanced in macrophages in response to LPS, IL-1 $\beta$, and IL-6, and also to be induced under Th17-polarizing conditions in T cells. We also found that Arid5a gene deficiency inhibited elevation of IL-6 levels in LPS-injected mice and preferential Th17-cell development in experimental autoimmune encephalomyelitis. Moreover, Arid5a counteracted the destabilizing function of regnase- 1 on IL- 6 mRNA (Fig. 3), indicating that the balance between Arid5a and regnase-1 plays an important role in IL-6 mRNA stability. All of these results suggest that posttranscriptional regulation of IL- 6 mRNA by Arid5a and regnase- 1 may play an important role in the expression of IL- 6 and that the predominance of Arid5a over regnase-1 promotes inflammatory processes and possibly induces the development of autoimmune inflammatory diseases.

During the so-called "cytokine storm," a potentially fatal immune reaction induced by hyperactivation of $\mathrm{T}$ cells, a major boost in IL-6 production is observed but without comparable production of other inflammatory cytokines. A recent study showed that the cytokine storm induced by cancer immunotherapy using $\mathrm{T}$ cell transfection was counteracted by the antiIL-6 receptor antibody, tocilizumab (Grupp et al. 2013). Experimentally, inhalation by mice of peroxidized phospholipids induced a cytokine storm resulting from a greatly marked increase in the production of IL-6 but not TNF (Imai et al. 2008).

These results showing the IL-6-specific elevation without any effect on the other inflammatory cytokines strongly suggest the impor-

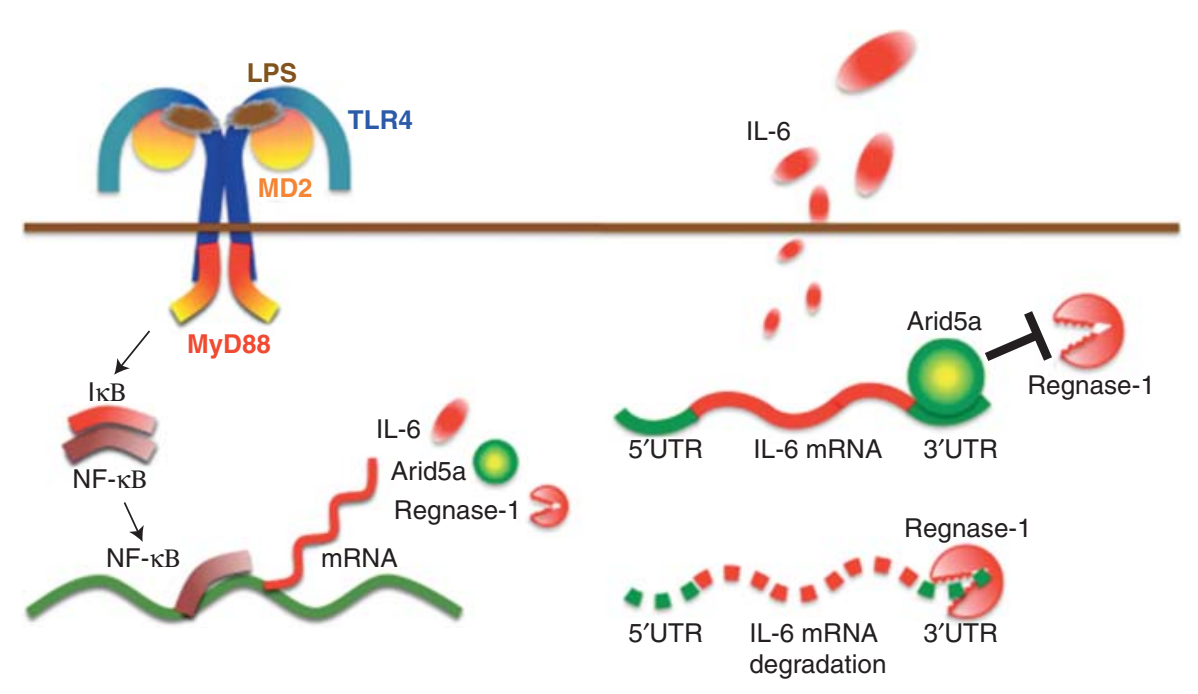

Figure 3. IL-6 synthesis and regulation of IL-6 mRNA stability by Arid5a. Pathogen-associated molecular patterns are recognized by pathogen-recognition receptors to induce proinflammatory cytokines; in this figure, TLR4 recognizes LPS and induces IL-6 mRNA via activation of the NF- $\kappa B$ signaling pathway. Regnase-1 promotes IL-6 mRNA degradation, whereas Arid5a inhibits destabilizing effects of regnase-1. The balance between Arid5a and regnase-1 is important for the regulation of IL-6 mRNA. MD2, myeloid differentiation protein 2; MyD88, myeloid differentiation primary response 88; IкB, inhibitor of NF- $\mathrm{B}$. 
T. Tanaka et al.

tance of posttranscriptional modification of IL6 mRNA by Arid5a and regnase-1. The balance between Arid5a and regnase-1 may determine the pathological increase of IL- 6 in various diseases including autoimmunity and even cytokine storm.

\section{IL-6 RECEPTOR-MEDIATED SIGNALING SYSTEM}

The IL-6 receptor-signaling system is made up of two receptor chains and downstream signaling molecules (Kishimoto et al. 1992). The IL-6 receptor (IL-6R) constitutes the IL-6-binding chain, which occurs in two forms, $80 \mathrm{kDa}$ transmembrane and 50-55 kDa- soluble IL-6R (sIL-6R), whereas $130 \mathrm{kDa}$ gp130 constitutes the signal-transducing chain. Both of these proteins belong to the cytokine receptor family with a Trp-Ser-X-Trp-Ser motif (Yamasaki et al. 1988; Hibi et al. 1990). sIL-6R without the cytoplasmic region is present in human serum and after IL-6 binding to sIL-6R; the resultant complex induces the IL-6 signal on gp130-expressing cells (Narazaki et al. 1993). The pleiotropic effect of IL-6 on various cells derives from the broad range of gp130 expression observed on cells (Taga and Kishimoto 1997). After binding of IL-6 to IL-6R, the IL-6/IL-6R complex in turn induces homodimerization of gp130 and triggers a downstream signal cascade (Fig. 4) (Murakami et al. 1993). The activated IL-6 receptor complex is generated in the form of a hexameric structure comprising two molecules each of IL-6, IL-6R, and gp130 (Boulanger et al. 2003). Of these components, IL-6R is a unique binding-receptor for IL-6, whereas the signal-transducing chain gp 130 is shared by members of the IL-6 family of cytokines, that is, leukemia inhibitory factor, oncostatin $\mathrm{M}$, ciliary neurotrophic factor, IL-11, cardiotrophin 1, cardiotrophin-like cytokine, IL-27, and IL-35. Although all of these cytokines thus bind to their specific binding receptors, they use the same gp130 for their signals (Kishimoto et al. 1994, 1995). The only exception is virus-encoded IL-6, which is the product of KSHV (also known as human herpesvirus 8), and directly binds to and activates gp130 (Aoki et al. 2001). The mechanism that the IL-6 cytokine family members use to employ the common signal transducer makes it clear why members of the IL-6 family show functional redundancy. The molecular elucidation of the IL-6-signaling system finally solved the long-standing mystery of why cytokines featured pleiotropy and redundancy.

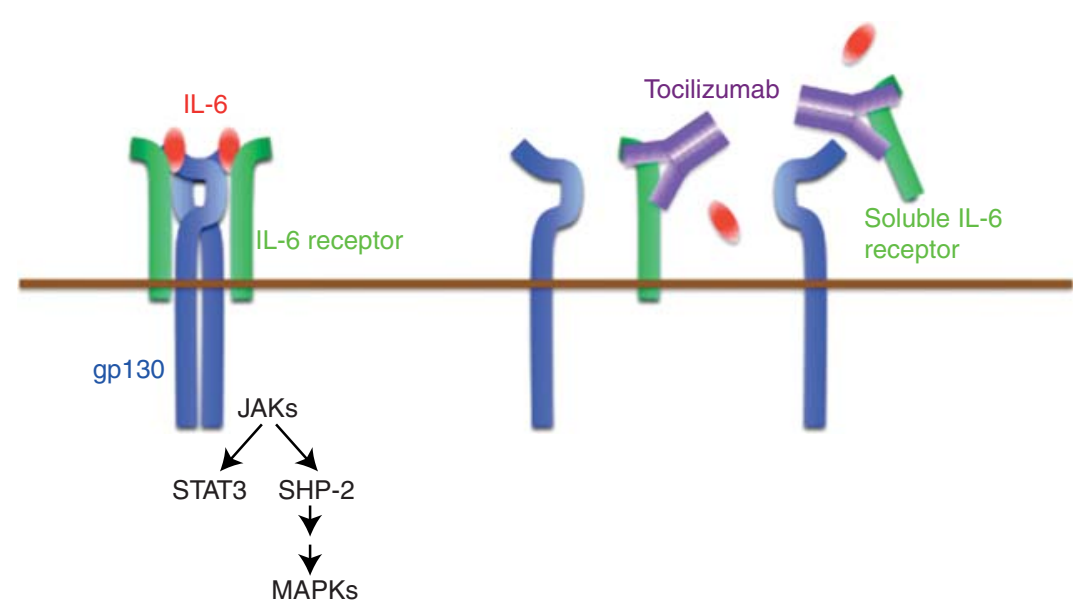

Figure 4. IL-6 receptor system and IL-6 blocker, a humanized anti-IL-6 receptor antibody tocilizumab. IL-6 binds to soluble and transmembrane IL-6R and the complex, then induces homodimerization of gp 130, leading to activation of the signaling system. A humanized anti-IL-6R antibody, tocilizumab, blocks IL-6-mediated signaling pathway by its inhibition of IL-6 binding to both receptors. JAKs, Janus kinases; SHP-2, SH2-domain containing protein tyrosine phosphatase- 2 . 
Activation of gp130 in turn triggers activation of downstream signaling molecules, that is, the Janus kinase (JAK)-STAT3 pathway and the JAK-SHP-2-mitogen-activated protein (MAP) kinase pathway. The regulation of various sets of IL-6 responsive genes, including acute phase proteins, is accounted for by the transcription factor STAT3, which also induces the suppressor of cytokine signaling 1 (SOCS1) and SOCS3, which share the SH2-domain. In this context, SOCS1 binds to tyrosine-phosphorylated JAK (Naka et al. 1997), whereas SOCS3 binds to tyrosine-phosphorylated gp130 (Schmitz et al. 2000) to stop IL-6 signaling by means of a negative feedback loop.

\section{IL-6 AND DISEASE}

An immediate and transient expression of IL-6 is generated in response to environmental stress factors such as infections and tissue injuries. This expression triggers an alarm signal and activates host defense mechanisms against stress. Removal of the source of stress from the host is followed by cessation of IL-6-mediated activation of the signal-transduction cascade by negative regulatory systems such as ligand-induced internalization and degradation of gp 130 and recruitment of SOCS (Naka et al. 1997), as well as degradation of IL- 6 mRNA by regnase- 1 leading to termination of IL-6 production. However, dysregulated and persistent IL-6 production of mostly unknown etiology, one of which may be the unbalance between Arid5a and regnase-1, in certain cell populations leads to the development of various diseases. This association of IL-6 with disease development was first shown in a case of cardiac myxoma. The culture of fluid obtained from the myxoma tissues of a patient who presented with fever, polyarthritis with positivity for antinuclear factor, elevated CRP level, and hypergammaglobulinemia, contained a large quantity of IL-6, which suggested that IL-6 may contribute to chronic inflammation and autoimmunity (Hirano et al. 1987). Subsequent studies have shown that dysregulation of IL-6 production occurs in the synovial cells of RA (Hirano et al. 1988), swollen lymph nodes of Castleman's disease
(Yoshizaki et al. 1989), myeloma cells (Kawano et al. 1988), and peripheral blood cells or involved tissues in various other autoimmune and chronic inflammatory diseases and even malignant cells in cancers (Nishimoto et al. 1989, 2005).

Moreover, the pathological role of IL-6 in disease development has been shown in numerous animal models of diseases as well as the fact that IL-6 blockade by means of gene knockout or administration of anti-IL-6 or anti-IL-6R Ab can result in the preventive or therapeutic suppression of disease development. For example, IL-6 blockade resulted in a noticeable reduction in susceptibility to Castleman's diseaselike symptoms in IL-6 transgenic mice (Katsume et al. 2002). Similar effects were observed in models of RA (Alonzi et al. 1998; Ohshima et al. 1998; Fujimoto et al. 2008), systemic lupus erythematosus (Mihara et al. 1998), systemic sclerosis (Kitaba et al. 2012), inflammatory myopathies (Okiyama et al. 2009), experimental autoimmune uveoretinitis (Haruta et al. 2011), experimental autoimmune encephalomyelitis (Serada et al. 2008), and many other diseases.

\section{IL-6 TARGETING AS STRATEGY FOR TREATMENT OF IMMUNE-MEDIATED DISEASES}

In view of the range of biological activities of IL6 and its pathological role in various diseases described above, it was anticipated that IL- 6 targeting would constitute a novel treatment strategy for various immune-mediated diseases. The development of tocilizumab was a direct result of this hypothesis. Tocilizumab is a humanized anti-IL-6R monoclonal Ab of the IgG1 class that was generated by grafting the complementarity determining regions of a mouse antihuman IL6R Ab onto human IgG1 (Sato et al. 1993), and it blocks IL-6-mediated signal transduction by inhibiting IL-6 binding to transmembrane and soluble IL-6R (Fig. 4). The outstanding efficacy, tolerability, and safety of tocilizumab were verified in numerous worldwide clinical trials initiated in the late 1990s. This has resulted in the approval of this biologic for the treatment of RA in more than 100 countries (Tanaka et al. 2013), 
T. Tanaka et al.

as well as for systemic and polyarticular juvenile idiopathic arthritis (Yokota et al. 2008, 2012; De Benedetti et al. 2012) and Castleman's disease (Nishimoto et al. 2005) in several countries. Although other biologics including TNF inhibitors, T-cell stimulator blocker, B-cell depletory, or IL-1R antagonist are currently used for RA, tocilizumab has proved its superior efficacy as monotherapy for moderate-to-severe active RA (Tanaka and Kishimoto 2011; Emery et al. 2013) and is recommended as a first-line biologic. Moreover, the outstanding efficacy of tocilizumab for systemic juvenile idiopathic arthritis has led to the recognition of the start of a new era in the treatment of this disease, which was long considered to be one of the most intractable juvenile diseases (Sandborg and Mellins 2012).

Furthermore, there are strong indications based on favorable results detailed in numerous recent case reports, series, and pilot studies of the off-label application of tocilizumab that it can be used for the treatment of various immune- mediated diseases (Tanaka and Kishimoto 2012; Tanaka et al. 2012). These comprise autoimmune, chronic inflammatory, autoinflammatory, and other diseases. The first group includes systemic sclerosis, inflammatory myopathies, large vessel vasculitis, systemic lupus erythematosus, relapsing polychondritis, autoimmune hemolytic anemia, acquired hemophilia A, neuromyelitis optica, and Cogan's syndrome. The second group includes adult-onset Still's disease, amyloid A amyloidosis, polymyalgia rheumatica, RS3PE, Bechet's disease, uveitis, Crohn's disease, graft-versus-host disease, pulmonary arterial hypertension, and IgG4-related diseases. The third group comprises such autoinflammatory diseases as TNF-receptor-associated periodic syndrome and chronic inflammatory neurological cutaneous articular syndrome, whereas other diseases include atherosclerosis, type 2 diabetes mellitus, atopic dermatitis, sciatica, and cancer-associated cachexia. Clinical trials are in progress to identify additional indications for tocilizumab (Table 1).

Table 1. Ongoing clinical trials of tocilizumab

\begin{tabular}{lll}
\hline Targeted diseases & Status & Identifier \\
\hline Diabetes mellitus (type 2), obesity & Phase 2 & NCT01073826 \\
Graves' ophthalmopathy & Phase 3 & NCT01297699 \\
Cardiovascular disease in RA (vs. etanercept) & Phase 4 & NCT01331837 \\
Polymyalgia rheumatica & Phase 2 & NCT01396317 \\
& Phase 2 & NCT01713842 \\
Giant-cell arteritis & Phase 2 & NCT01450137 \\
& Phase 3 & NCT01791153 \\
Steroid refractory acute GVHD & Phase 1/2 & NCT01475162 \\
After HSCT & Phase 2 & NCT01757197 \\
Non-ST elevation myocardial infarction & Phase 2 & NCT01491074 \\
Noninfectious uveitis & Phase 1/2 & NCT01717170 \\
Systemic sclerosis & Phase 2/3 & NCT01532869 \\
Transplant rates awaiting kidney transplantation & Phase 1/2 & NCT01594424 \\
JIA-associated uveitis & Phase 1/2 & NCT01603355 \\
Recurrent ovarian cancer & Phase 1/2 & NCT01637532 \\
Behcet's syndrome & Phase 2 & NCT01693653 \\
Schizophrenia & Phase 1 & NCT01696929 \\
Erdheim-Chester disease & Phase 2 & NCT01727206 \\
Primary Sjogren's syndrome & Phase 2/3 & NCT01782235 \\
Fibrous dysplasia of bone & Phase 2 & NCT01791842
\end{tabular}

Registered with ClinicalTrials.gov for diseases other than rheumatoid arthritis, juvenile idiopathic arthritis, and Castleman's disease.

GVHD, graft-versus-host disease; HSCT, hematopoietc stem cell transplant; JIA, juvenile idiopathic arthritis. 


\section{CONCLUDING REMARKS AND FUTURE PROSPECTS}

The first report of the existence of soluble factors for the enhancement of IgG and IgE Ab responses was published by Kishimoto and Ishizaka in 1973, and it took 13 years until the actual cloning of the IL-6 gene (Hirano et al. 1986). After this success, the fundamental research progressed rapidly and the whole picture of the IL- 6 signaling system was completed in the early 1990s (Kishimoto et al. 1994). In parallel with this development, the pathological involvement of IL-6 in various diseases was also established (Nishimoto et al. 1989, 2005; Yoshizaki et al. 1989). It was found that if free serum concentration of tocilizumab is maintained at more than
$1 \mu \mathrm{g} / \mathrm{ml}$, CRP remains negative (Nishimoto et al. 2008), indicating that IL-6 plays a major role in the induction of CRP expression and that IL-6 may be involved in the development of almost all chronic inflammatory diseases with CRP elevation. Clinical trials of tocilizumab started in the late 1990s and this humanized monoclonal $\mathrm{Ab}$ was approved for the treatment of Castleman's disease in 2005 in Japan, nearly 20 years after the successful molecular cloning of the IL-6 gene (Fig. 5) (Kishimoto 2005). During the following years, tocilizumab has become a first-line biologic for the treatment of moderate-to-severe active RA and the only approved first-line biologic for systemic juvenile idiopathic arthritis. It is anticipated that during the next decade this IL- 6 blocker will be widely used for

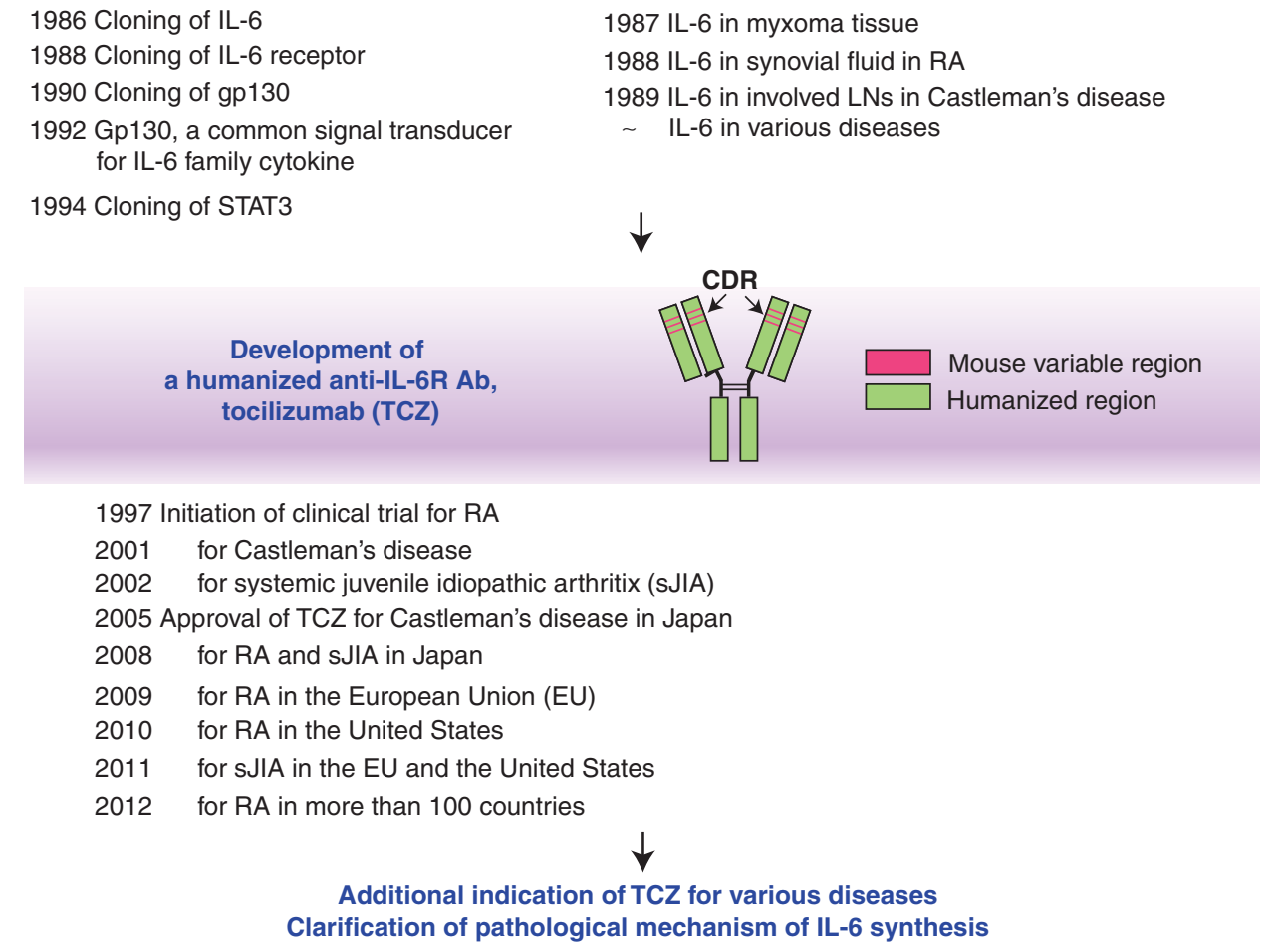

Figure 5. Major discoveries in IL-6-related research and establishment of IL-6 targeting strategy for immunemediated diseases. Basic research regarding IL-6 clarified the molecular basis of the characteristics of cytokine, redundancy, and pleiotropy, whereas clinical research revealed its pathological significance in disease development. These findings led to concept that IL-6 targeting would constitute a novel therapeutic strategy for immune-mediated diseases and indeed, tocilizumab, a humanized anti-IL-6R antibody became an innovative biologic for the treatment of intractable diseases such as RA, systemic juvenile idiopathic arthritis (sJIA), and Castleman's disease. It will be expected that this strategy would be widely applicable for other immune-mediated diseases. LNs, lymph nodes; TCZ, tocilizumab; CDR, complementarity determining region. 
T. Tanaka et al.

the treatment of various as-yet intractable diseases including cytokine storm and its application will overcome the refractoriness of such diseases.

To achieve this goal, however, there are several hurdles to overcome. First, additional clinical trials will be needed to evaluate the efficacy and safety of tocilizumab for various diseases. The second, and also important, hurdle is to clarify the mechanisms that render tocilizumab efficacious for phenotypically different diseases. In the case of amyloid A amyloidosis, the ameliorative effect of tocilizumab can be explained by its potent suppression of serum amyloid A protein synthesis (Tanaka et al. 2011). In the case of RA, it has been shown that tocilizumab treatment led to improvement in systemic and joint inflammatory markers (Garnero et al. 2010; Terpos et al. 2011; Kanbe et al. 2012), but it remained to be determined whether it can rectify fundamental immunological abnormalities, such as autoantibody production or imbalance of effector $\mathrm{CD} 4^{+}$T-cell subsets ( $\mathrm{Ta}$ naka 2013). However, recent preliminary results indicate that tocilizumab treatment can correct the imbalance between Th17 and Treg in peripheral blood $\mathrm{CD}^{+}{ }^{+} \mathrm{T}$ cells (Samson et al. 2012; Pesce et al. 2013). Moreover, it was shown that the treatment caused a reduction in the level of serum IgG4-class anticyclic citrullinated peptide Ab in RA (Carbone et al. 2013). Anti-aquaporin 4 (AQP4) Ab plays a pathological role in neuromyelitis optica, and tocilizumab treatment was found to improve clinical symptoms and reduce serum anti-AQP4 Ab titers, perhaps by inhibiting cell survival of the plasmablasts secreting this Ab (Chihara et al. 2011; Araki et al. 2013). If IL-6 blockade can actually correct these immunological abnormalities, it will in fact be possible to use tocilizumab for the treatment of a wide variety of immune-mediated diseases.

Finally, the mystery remains why IL-6 is persistently expressed in distinct cell populations in various diseases. Accurate and detailed analyses of proteins such as Arid5a and regnase-1 and of microRNAs that regulate IL-6 synthesis will be helpful for solving this mystery, whereas clarification of the mechanism(s) involved will facilitate the identification of more specific target molecules and investigations into the pathogenesis of specific diseases.

\section{ACKNOWLEDGMENTS}

T.K. holds a patent of tocilizumab and has received royalties for Actemra. T.T. received grants and payment for lectures including service on speaker's bureaus from Chugai Pharmaceutical Co., Ltd. M.N. received payment for lectures including service on speaker's bureaus from Chugai Pharmaceutical Co., Ltd.

\section{REFERENCES}

Akira S, Kishimoto T. 1992. IL-6 and NF-IL6 in acute-phase response and viral infection. Immunol Rev 127: 25-50.

Akira S, Taga T, Kishimoto T. 1993. Interleukin-6 in biology and medicine. Adv Immunol 54: 1-78.

Alonzi T, Fattori E, Lazzaro D, Costa P, Probert L, Kollias G, De Benedetti F, Poli V, Ciliberto G. 1998. Interleukin 6 is required for the development of collagen-induced arthritis. J Exp Med 187: 461-468.

Ambrosino C, Ruocco MR, Chen X, Mallardo M, Baudi F, Trematerra S, Quinto I, Venuta S, Scala G. 1997. HIV-1 Tat induces the expression of the interleukin-6 (IL6) gene by binding to the IL6 leader RNA and by interacting with CAAT enhancer-binding protein $\beta$ (NF-IL6) transcription factors. J Biol Chem 272: 14883-14892.

Anderson P. 2008. Post-transcriptional control of cytokine production. Nature Immunol 9: 353-359.

Aoki Y, Narazaki M, Kishimoto T, Tosato G. 2001. Receptor engagement by viral interleukin- 6 encoded by Kaposi sarcoma-associated herpesvirus. Blood 98: 3042-3049.

Araki M, Aranami T, Matsuoka T, Nakamura M, Miyake S, Yamamura T. 2013. Clinical improvement in a patient with neuromyelitis optica following therapy with the anti-IL-6 receptor monoclonal antibody tocilizumab. Mod Rheumatol 23: 827-831.

Ballard DW, Bohnlein E, Lowenthal JW, Wano Y, Franza BR, Greene WC. 1988. HTLV-I tax induces cellular proteins that activate the $\kappa \mathrm{B}$ element in the IL-2 receptor $\alpha$ gene. Science 241: 1652-1655.

Bell DR, Poland A. 2000. A binding of aryl hydrocarbon receptor $(\mathrm{AhR})$ to $\mathrm{AhR}$-interacting protein. The role of hsp90. J Biol Chem 275: 36407-36414.

Bettelli E, Carrier Y, Gao W, Korn T, Strom TB, Oukka M, Weiner HL, Kuchroo VK. 2006. Reciprocal developmental pathways for the generation of pathogenic effector TH17 and regulatory T cells. Nature 441: 235-238.

Bianchi ME. 2007. DAMPs, PAMPs and alarmins: All we need to know about danger. J Leukoc Biol 81: 1-5.

Boulanger MJ, Chow DC, Brevnova EE, Garcia KC. 2003. Hexameric structure and assembly of the interleukin-6/ IL-6 $\alpha$-receptor/gp130 complex. Science 300: 21012104. 
Burbach KM, Poland A, Bradfield CA. 1992. Cloning of the Ah-receptor cDNA reveals a distinctive ligand-activated transcription factor. Proc Natl Acad Sci 89: 8185-8189.

Carbone G, Wilson A, Diehl SA, Bunn J, Cooper SM, Rincon M. 2013. Interleukin-6 receptor blockade selectively reduces IL-21 production by CD4 T cells and IgG4 autoantibodies in rheumatoid arthritis. Int J Biol Sci 9: 279288.

Chen CY, Shyu AB. 1995. AU-rich elements: Characterization and importance in mRNA degradation. Trends Biochem Sci 20: 465-470.

Chen Q, Wang H, Liu Y, Song Y, Lai L, Han Q, Cao X, Wang Q. 2012. Inducible microRNA-223 down-regulation promotes TLR-triggered IL- 6 and IL- $1 \beta$ production in macrophages by targeting STAT3. PLoS ONE 7: e42971.

Chihara N, Aranami T, Sato W, Miyazaki Y, Miyake S, Okamoto T, Ogawa M, Toda T, Yamamura T. 2011. Interleukin 6 signaling promotes anti-aquaporin 4 autoantibody production from plasmablasts in neuromyelitis optica. Proc Natl Acad Sci 108: 3701-3706.

De Benedetti F, Brunner HI, Ruperto N, Kenwright A, Wright S, Calvo I, Cuttica R, Ravelli A, Schneider R, Woo P, et al. 2012. Randomized trial of tocilizumab in systemic juvenile idiopathic arthritis. N Engl J Med 367: 2385-2395.

Delerive P, De Bosscher K, Besnard S, Vanden Berghe W, Peters JM, Gonzalez FJ, Fruchart JC, Tedgui A, Haegeman G, Staels B. 1999. Peroxisome proliferator-activated receptor $\alpha$ negatively regulates the vascular inflammatory gene response by negative cross-talk with transcription factors NF-кB and AP-1. J Biol Chem 274: 32048-32054.

Dragan YP, Schrenk D. 2000. Animal studies addressing the carcinogenicity of TCDD (or related compounds) with an emphasis in tumour promotion. Food Addit Contam 17: 289-302.

Duncan MR, Berman B. 1991. Stimulation of collagen and glycosaminoglycan production in cultured human adult dermal fibroblasts by recombinant human interleukin 6 . J Invest Dermatol 97: 686-692.

Ema M, Sogawa K, Watanabe N, Chujoh Y, Matsushita N, Gotoh O, Funae Y, Fujii-Kuriyama Y. 1992. cDNA cloning and structure of mouse putative Ah receptor. Biochem Biophys Res Commun 184: 246-253.

Emery P, Sebba A, Huizinga TW. 2013. Biologic and oral disease-modifying antirheumatic drug monotherapy in rheumatoid arthritis. Ann Rheum Dis 72: 1897-1904 .

Fishman D, Faulds G, Jeffery R, Mohamed-Ali V, Yudkin JS, Humphries S, Woo P. 1998. The effect of novel polymorphisms in the interleukin-6 (IL-6) gene on IL-6 transcription and plasma IL-6 levels, and an association with systemic-onset juvenile chronic arthritis. J Clin Invest 102: 1369-1376.

Fujii-Kuriyama Y, Ema M, Miura J, Sogawa K. 1994. Ah receptor: A novel ligand-activated transcription factor. Exp Clin Immunogenet 1: 65-74.

Fujimoto M, Serada S, Mihara M, Uchiyama Y, Yoshida H, Koike N, Ohsugi Y, Nishikawa T, Ripley B, Kimura A, et al. 2008. Interleukin-6 blockade suppresses autoimmune arthritis in mice by the inhibition of inflammatory Th17 responses. Arthritis Rheum 58: 3710-3719.

Garnero P, Thompson E, Woodworth T, Smolen JS. 2010. Rapid and sustained improvement in bone and cartilage turnover markers with the anti-interleukin-6 receptor inhibitor tocilizumab plus methotrexate in rheumatoid arthritis patients with an inadequate response to methotrexate: Results from a substudy of the multicenter double-blind, placebo-controlled trial of tocilizumab in inadequate responders to methotrexate alone. Arthritis Rheum 62: 33-43.

Gillmore JD, Lovat LB, Persey MR, Pepys MB, Hawkins PN. 2001. Amyloid load and clinical outcome in AA amyloidosis in relation to circulating concentration of serum amyloid A protein. Lancet 358: 24-29.

Grossman RM, Krueger J, Yourish D, Granelli-Piperno A, Murphy DP, May LT, Kupper TS, Sehgal PB, Gottlieb AB. 1989. Interleukin 6 is expressed in high levels in psoriatic skin and stimulates proliferation of cultured human keratinocytes. Proc Natl Acad Sci 86: 6367-6371.

Grupp SA, Kalos M, Barrett D, Aplenc R, Porter DL, Rheingold SR, Teachey DT, Chew A, Hauck B, Wright JF, et al. 2013. Chimeric antigen receptor-modified $T$ cells for acute lymphoid leukemia. N Engl J Med 368: 1509-1518.

Harrington LE, Hatton RD, Mangan PR, Turner H, Murphy TL, Murphy KM, Weaver CT. 2005. Interleukin 17-producing $\mathrm{CD}^{+}{ }^{+}$effector $\mathrm{T}$ cells develop via a lineage distinct from the Thelper type 1 and 2 lineages. Nat Immunol 6: 1123-1132.

Haruta H, Ohguro N, Fujimoto M, Hohki S, Terabe F, Serada S, Nomura S, Nishida K, Kishimoto T, Naka T. 2011. Blockade of interleukin-6 signaling suppresses not only th17 but also interphotoreceptor retinoid binding protein-specific Th1 by promoting regulatory $\mathrm{T}$ cells in experimental autoimmune uveoretinitis. Invest Ophthalmol Vis Sci 52: 3264-3271.

Hashizume M, Hayakawa N, Mihara M. 2008. IL-6 transsignalling directly induces RANKL on fibroblast-like synovial cells and is involved in RANKL induction by TNF- $\alpha$ and IL-17. Rheumatology (Oxford) 47: 16351640.

Hashizume M, Hayakawa N, Suzuki M, Mihara M. 2009. IL$6 /$ sIL-6R trans-signalling, but not TNF- $\alpha$ induced angiogenesis in a HUVEC and synovial cell co-culture system. Rheumatol Int 29: 1449-1454.

He M, Xu Z, Ding T, Kuang DM, Zheng L. 2009. MicroRNA155 regulates inflammatory cytokine production in tumor-associated macrophages via targeting C/EBP 3 . Cell Mol Immunol 6: 343-352.

Heinrich PC, Castell JV, Andus T. 1990. Interleukin-6 and the acute phase response. Biochem J 265: 621-636.

Hibi M, Murakami M, Saito M, Hirano T, Taga T, Kishimoto T. 1990. Molecular cloning and expression of an IL-6 signal transducer, gp130. Cell 63: 1149-1157.

Hirano T, Yasukawa K, Harada H, Taga T, Watanabe Y, Matsuda T, Kashiwamura S, Nakajima K, Koyama K, Iwamatsu A, et al. 1986. Complementary DNA for a novel human interleukin (BSF-2) that induces B lymphocytes to produce immunoglobulin. Nature 324: 73-76.

Hirano T, Taga T, Yasukawa K, Nakajima K, Nakano N, Takatsuki F, Shimizu M, Murashima A, Tsunasawa S, Sakiyama F, et al. 1987. Human B-cell differentiation factor defined by an anti-peptide antibody and its possible role in autoantibody production. Proc Natl Acad Sci 84: 228 231. 
T. Tanaka et al.

Hirano T, Matsuda T, Turner M, Miyasaka N, Buchan G Tang B, Sato K, Shimizu M, Maini R, Feldmann M, et al. 1988. Excessive production of interleukin 6/B cell stimulatory factor-2 in rheumatoid arthritis. Eur J Immunol 18: $1797-1801$.

Hirano T, Akira S, Taga T, Kishimoto T. 1990. Biological and clinical aspects of interleukin 6. Immunol Today 11: 443449.

Imai Y, Kuba K, Neely GG, Yaghubian-Malhami R, Perkmann T, van Loo G, Ermolaeva M, Veldhuizen R, Leung $\mathrm{YH}$, Wang $\mathrm{H}$, et al. 2008. Identification of oxidative stress and Toll-like receptor 4 signaling as a key pathway of acute lung injury. Cell 133: 235-249.

Ishibashi T, Kimura H, Shikama Y, Uchida T, Kariyone S, Hirano T, Kishimoto T, Takatsuki F, Akiyama Y. 1989. Interleukin-6 is a potent thrombopoietic factor in vivo in mice. Blood 74: 1241-1244.

Ivanov II, McKenzie BS, Zhou L, Tadokoro CE, Lepelley A, Lafaille JJ, Cua DJ, Littman DR. 2006. The orphan nuclear receptor ROR $\gamma$ directs the differentiation program of proinflammatory $\mathrm{IL}-17^{+}$T helper cells. Cell 126: 1121 1133.

Iwasaki H, Takeuchi O, Teraguchi S, Matsushita K, Uehata T, Kuniyoshi K, Satoh T, Saitoh T, Matsushita M, Standley DM, et al. 2011. The ІкB kinase complex regulates the stability of cytokine-encoding mRNA induced by TLRIL-1R by controlling degradation of regnase- 1 . Nat Immunol 12: 1167-1175.

Jilka RL, Hangoc G, Girasole G, Passeri G, Williams DC, Abrams JS, Boyce B, Broxmeyer H, Manolagas SC. 1992. Increased osteoclast development after estrogen loss: mediation by interleukin-6. Science 257: 88-91.

Jux B, Kadow S, Esser C. 2009. Langerhans cell maturation and contact hypersensitivity are impaired in aryl hydrocarbon receptor-null mice. J Immunol 182: 6709-6717.

Kanbe K, Nakamura A, Inoue Y, Hobo K. 2012. Osteoprotegerin expression in bone marrow by treatment with tocilizumab in rheumatoid arthritis. Rheumatol Int 32: 2669-2674.

Kang JG, Pripuzova N, Majerciak V, Kruhlak M, Le SY, Zheng ZM. 2011. Kaposi's sarcoma-associated herpesvirus ORF57 promotes escape of viral and human interleukin-6 from microRNA-mediated suppression. J Virol 85: $2620-2630$.

Katsume A, Saito H, Yamada Y, Yorozu K, Ueda O, Akamatsu K, Nishimoto N, Kishimoto T, Yoshizaki K, Ohsugi Y. 2002. Anti-interleukin 6 (IL-6) receptor antibody suppresses Castleman's disease like symptoms emerged in IL6 transgenic mice. Cytokine 20: 304-311.

Kawano M, Hirano T, Matsuda T, Taga T, Horii Y, Iwato K, Asaoku H, Tang B, Tanabe O, Tanaka H, et al. 1988. Autocrine generation and requirement of BSF-2/IL-6 for human multiple myelomas. Nature 332: 83-85.

Kimura A, Kishimoto T. 2010. IL-6: Regulator of Treg/Th17 balance. Eur J Immunol 40: 1830-1835.

Kimura A, Naka T, Nohara K, Fujii-Kuriyama Y, Kishimoto T. 2008. Aryl hydrocarbon receptor regulates Stat lactivation and participates in the development of Th17 cells. Proc Natl Acad Sci 105: 9721-9726.

Kimura A, Naka T, Nakahama T, Chinen I, Masuda K, Nohara K, Fujii-Kuriyama Y, Kishimoto T. 2009. Aryl hydrocarbon receptor in combination with Statl regulates
LPS-induced inflammatory responses. J Exp Med 206: 2027-2035.

Kishimoto T. 1985. Factors affecting B-cell growth and differentiation. Annu Rev Immunol 3: 133-157.

Kishimoto T. 1989. The biology of interleukin-6. Blood 74: $1-10$.

Kishimoto T. 2005. Interleukin-6: From basic science to medicine-40 years in immunology. Annu Rev Immunol 23: $1-21$.

Kishimoto T, Ishizaka K. 1973. Regulation of antibody response in vitro: VII. Enhancing soluble factors for IgG and IgE antibody response. J Immunol 111: 1194-1205.

Kishimoto T, Akira S, Taga T. 1992. Interleukin-6 and its receptor: A paradigm for cytokines. Science 258: $593-$ 597.

Kishimoto T, Taga T, Akira S. 1994. Cytokine signal transduction. Cell 76: 253-262.

Kishimoto T, Akira S, Narazaki M, Taga T. 1995. Interleukin6 family of cytokines and gp 130. Blood 86: 1243-1254.

Kitaba S, Murota H, Terao M, Azukizawa H, Terabe F, Shima Y, Fujimoto M, Tanaka T, Naka T, Kishimoto T, et al. 2012. Blockade of interleukin- 6 receptor alleviates disease in mouse model of scleroderma. Am J Pathol 180: 165-176.

Korn T, Bettelli E, Oukka M, Kuchroo VK. 2009. IL-17 and Th17 cells. Annu Rev Immunol 27: 485-517.

Kotake S, Sato K, Kim KJ, Takahashi N, Udagawa N, Nakamura I, Yamaguchi A, Kishimoto T, Suda T, Kashiwazaki S. 1996. Interleukin-6 and soluble interleukin-6 receptors in the synovial fluids from rheumatoid arthritis patients are responsible for osteoclast-like cell formation. J Bone Miner Res 11: 88-95.

Kumar H, Kawai T, Akira S. 2011. Pathogen recognition by the innate immune system. Int Rev Immunol 30: 16-34.

Laurence A, Tato CM, Davidson TS, Kanno Y, Chen Z, Yao Z, Blank RB, Meylan F, Siegel R, Hennighausen L, et al. 2007. Interleukin-2 signaling via STAT5 constrains T helper 17 cell generation. Immunity 26: 371-381.

Lee YH, Bae SC, Choi SJ, Ji JD, Song GG. 2012. The association between interleukin- 6 polymorphisms and rheumatoid arthritis: A meta-analysis. Inflamm Res 61: 665671.

Leung K, Nabel GJ. 1988. HTLV-1 transactivator induces interleukin-2 receptor expression through an NF-кBlike factor. Nature 333: 776-778.

Libermann TA, Baltimore D. 1990. Activation of interleukin-6 gene expression through the NF-кB transcription factor. Mol Cell Biol 10: 2327-2334.

Liuzzi JP, Lichten LA, Rivera S, Blanchard RK, Aydemir TB, Knutson MD, Ganz T, Cousins RJ. 2005. Interleukin-6 regulates the zinc transporter Zip14 in liver and contributes to the hypozincemia of the acute-phase response. Proc Natl Acad Sci 102: 6843-6848.

Ma CS, Deenick EK, Batten M, Tangye SG. 2012. The origins, function, and regulation of $\mathrm{T}$ follicular helper cells. J Exp Med 209: 1241-1253.

Mahe Y, Mukaida N, Kuno K, Akiyama M, Ikeda N, Matsushima K, Murakami S. 1991. Hepatitis B virus X protein transactivates human interleukin- 8 gene through acting on nuclear factor $\mathrm{\kappa B}$ and CCAAT/enhancer-binding protein-like cis-elements. J Biol Chem 266: 13759-13763. 
Masuda K, Ripley B, Nishimura R, Mino T, Takeuchi O, Shioi G, Kiyonari H, Kishimoto T. 2013. Arid5a controls IL-6 mRNA stability, which contributes to elevation of IL-6 level in vivo. Proc Natl Acad Sci 110: 9409-9414.

Matsusaka T, Fujikawa K, Nishio Y, Mukaida N, Matsushima K, Kishimoto T, Akira S. 1993. Transcription factors NFIL6 and NF- $\kappa$ B synergistically activate transcription of the inflammatory cytokines, interleukin 6 and interleukin 8. Proc Natl Acad Sci 90: 10193-10197.

Matsushita K, Takeuchi O, Standley DM, Kumagai Y, Kawagoe T, Miyake T, Satoh T, Kato H, Tsujimura T, Nakamura $\mathrm{H}$, et al. 2009. Zc3h12a is an RNase essential for controlling immune responses by regulating mRNA decay. $\mathrm{Na}$ ture 458: 1185-1190.

Mihara M, Takagi N, Takeda Y, Ohsugi Y. 1998. IL-6 receptor blockage inhibits the onset of autoimmune kidney disease in NZB/W F1 mice. Clin Exp Immunol 112: 397402.

Murakami M, Hibi M, Nakagawa N, Nakagawa T, Yasukawa K, Yamanishi K, Taga T, Kishimoto T. 1993. IL-6-induced homodimerization of gp130 and associated activation of a tyrosine kinase. Science 260: 1808-1810.

Naka T, Narazaki M, Hirata M, Matsumoto T, Minamoto S, Aono A, Nishimoto N, Kajita T, Taga T, Yoshizaki K, et al. 1997. Structure and function of a new STAT-induced STAT inhibitor. Nature 387: 924-929.

Nakahama T, Kimura A, Nguyen NT, Chinen I, Hanieh H, Nohara K, Fujii-Kuriyama Y, Kishimoto T. 2011. Aryl hydrocarbon receptor deficiency in $\mathrm{T}$ cells suppresses the development of collagen-induced arthritis. Proc Natl Acad Sci 108: 14222-14227.

Nakahama T, Hanieh H, Nguyen NT, Chinen I, Ripley B, Millrine D, Lee S, Nyati KK, Dubey PK, Chowdhury K, et al. 2013. Aryl hydrocarbon receptor-mediated induction of the microRNA-132/212 cluster promotes interleukin-17-producing T-helper cell differentiation. Proc Natl Acad Sci 110: 11964-11969.

Nakahara H, Song J, Sugimoto M, Hagihara K, Kishimoto T, Yoshizaki K, Nishimoto N. 2003. Anti-interleukin-6 receptor antibody therapy reduces vascular endothelial growth factor production in rheumatoid arthritis. Arthritis Rheum 48: 1521-1529.

Narazaki M, Yasukawa K, Saito T, Ohsugi Y, Fukui H, Koishihara Y, Yancopoulos GD, Taga T, Kishimoto T. 1993. Soluble forms of the interleukin-6 signal-transducing receptor component gp130 in human serum possessing a potential to inhibit signals through membrane-anchored gp130. Blood 82: 1120-1126.

Nemeth E, Rivera S, Gabayan V, Keller C, Taudorf S, Pedersen BK, Ganz T. 2004. IL-6 mediates hypoferremia of inflammation by inducing the synthesis of the iron regulatory hormone hepcidin. J Clin Invest 113: 1271-1276.

Nguyen NT, Kimura A, Nakahama T, Chinen I, Masuda K, Nohara K, Fujii-Kuriyama Y, Kishimoto T. 2010. Aryl hydrocarbon receptor negatively regulates dendritic cell immunogenicity via a kynurenine-dependent mechanism. Proc Natl Acad Sci 107: 19961-19966.

Nishimoto N, Yoshizaki K, Tagoh H, Monden M, Kishimoto S, Hirano T, Kishimoto T. 1989. Elevation of serum interleukin 6 prior to acute phase proteins on the inflammation by surgical operation. Clin Immunol Immunopathol 50: 399-401.
Nishimoto N, Kanakura Y, Aozasa K, Johkoh T, Nakamura M, Nakano S, Nakano N, Ikeda Y, Sasaki T, Nishioka K, et al. 2005. Humanized anti-interleukin-6 receptor antibody treatment of multicentric Castleman disease. Blood 106: $2627-2632$.

Nishimoto N, Terao K, Mima T, Nakahara H, Takagi N, Kakehi T. 2008. Mechanisms and pathologic significances in increase in serum interleukin-6 (IL-6) and soluble IL-6 receptor after administration of an anti-IL-6 receptor antibody, tocilizumab, in patients with rheumatoid arthritis and Castleman disease. Blood 112: 3959-3964.

Ohno H, Kaneko S, Lin Y, Kobayashi K, Murakami S. 1999. Human hepatitis B virus X protein augments the DNA binding of nuclear factor for IL-6 through its basic-leucine zipper domain. J Med Virol 58: 11-18.

Ohshima S, Saeki Y, Mima T, Sasai M, Nishioka K, Nomura S, Kopf M, Katada Y, Tanaka T, Suemura M, et al. 1998. Interleukin 6 plays a key role in the development of antigen-induced arthritis. Proc Natl Acad Sci 95: 82228226.

Ohtake F, Takeyama K, Matsumoto T, Kitagawa H, Yamamoto Y, Nohara K, Tohyama C, Krust A, Mimura J, Chambon P, et al. 2003. Modulation of oestrogen receptor signalling by association with the activated dioxin receptor. Nature 423: 545-550.

Okada M, Kitahara M, Kishimoto S, Matsuda T, Hirano T, Kishimoto T. 1988. IL-6/BSF-2 functions as a killer helper factor in the in vitro induction of cytotoxic T cells. $J$ Immunol 141: 1543-1549.

Okiyama N, Sugihara T, Iwakura Y, Yokozeki H, Miyasaka N, Kohsaka H. 2009. Therapeutic effects of interleukin-6 blockade in a murine model of polymyositis that does not require interleukin-17A. Arthritis Rheum 60: 25052512.

Palanisamy V, Jakymiw A, Van Tubergen EA, D’Silva NJ, Kirkwood KL. 2012. Control of cytokine mRNA expression by RNA-binding proteins and microRNAs. J Dent Res 91: 651-658.

Pesce B, Soto L, Sabugo F, Wurmann P, Cuchacovich M, Lopez MN, Sotelo PH, Molina MC, Aguillon JC, Catalan D. 2013. Effect of interleukin-6 receptor blockade on the balance between regulatory $\mathrm{T}$ cells and T helper type 17 cells in rheumatoid arthritis patients. Clin Exp Immunol 171: 237-242.

Poli V, Balena R, Fattori E, Markatos A, Yamamoto M, Tanaka H, Ciliberto G, Rodan GA, Costantini F. 1994. Interleukin-6 deficient mice are protected from bone loss caused by estrogen depletion. EMBO J 13: 1189-1196.

Puga A, Tomlinson CR, Xia Y. 2005. Ah receptor signals cross-talk with multiple developmental pathways. Biochem Pharmacol 69: 199-207.

Ray A, Prefontaine KE. 1994. Physical association and functional antagonism between the $\mathrm{p} 65$ subunit of transcription factor NF- $\mathrm{kB}$ and the glucocorticoid receptor. Proc Natl Acad Sci 91: 752-756.

Samson M, Audia S, Janikashvili N, Ciudad M, Trad M, Fraszczak J, Ornetti P, Maillefert JF, Miossec P, Bonnotte B. 2012. Brief report: Inhibition of interleukin- 6 function corrects Th17/Treg cell imbalance in patients with rheumatoid arthritis. Arthritis Rheum 64: 2499-2503. 
T. Tanaka et al.

Sandborg C, Mellins ED. 2012. A new era in the treatment of systemic juvenile idiopathic arthritis. N Engl J Med 367: 2439-2440.

Santhanam U, Ray A, Sehgal PB. 1991. Repression of the interleukin 6 gene promoter by p53 and the retinoblastoma susceptibility gene product. Proc Natl Acad Sci 88: 7605-7609.

Sato K, Tsuchiya M, Saldanha J, Koishihara Y, Ohsugi Y, Kishimoto T, Bendig MM. 1993. Reshaping a human antibody to inhibit the interleukin 6-dependent tumor cell growth. Cancer Res 53: 851-856.

Scala G, Ruocco MR, Ambrosino C, Mallardo M, Giordano V, Baldassarre F, Dragonetti E, Quinto I, Venuta S. 1994. The expression of the interleukin 6 gene is induced by the human immunodeficiency virus 1 TAT protein. J Exp Med 179: 961-971.

Schmitz J, Weissenbach M, Haan S, Heinrich PC, Schaper F. 2000. SOCS3 exerts its inhibitory function on interleukin-6 signal transduction through the SHP2 recruitment sites of gp130. J Biol Chem 275: 12848-12856.

Serada S, Fujimoto M, Mihara M, Koike N, Ohsugi Y, Nomura S, Yoshida H, Nishikawa T, Terabe F, Ohkawara T, et al. 2008. IL-6 blockade inhibits the induction of myelin antigen-specific Th17 cells and Th1 cells in experimental autoimmune encephalomyelitis. Proc Natl Acad Sci 105: 9041-9046.

Sims GP, Rowe DC, Rietdijk ST, Herbst R, Coyle AJ. 2010. HMGB1 and RAGE in inflammation and cancer. Annu Rev Immunol 28: 367-388.

Stumhofer JS, Laurence A, Wilson EH, Huang E, Tato CM, Johnson LM, Villarino AV, Huang Q, Yoshimura A, Sehy D, et al. 2006. Interleukin 27 negatively regulates the development of interleukin 17-producing $\mathrm{T}$ helper cells during chronic inflammation of the central nervous system. Nat Immunol 7: 937-945.

Taga T, Kishimoto T. 1997. Gp130 and the interleukin-6 family of cytokines. Annu Rev Immunol 15: 797-819.

Tanaka T. 2013. Can IL-6 blockade rectify imbalance between Tregs and Th17 cells? Immunotherapy 5: 695-697.

Tanaka T, Kishimoto T. 2011. Immunotherapy of tocilizumab for rheumatoid arthritis. J Clin Cell Immunol S6: 001.

Tanaka T, Kishimoto T. 2012. Targeting interleukin-6: All the way to treat autoimmune and inflammatory diseases. Int J Biol Sci 8: 1227-1236.

Tanaka T, Hagihara K, Hishitani Y, Ogata A. 2011. Tocilizumab for the treatment of AA amyloidosis. In Amyloidosis-An insight to disease of systems and novel therapies (ed. Isil Adadan Guvenc MD), pp. 155-170. InTech Open Access, Rijeka, Croatia.

Tanaka T, Narazaki M, Kishimoto T. 2012. Therapeutic targeting of the interleukin-6 receptor. Annu Rev Pharmacol Toxicol 52: 199-219.

Tanaka T, Ogata A, Narazaki M. 2013. Tocilizumab: An updated review of its use in the treatment of rheumatoid arthritis and its application for other immune-mediated diseases. Clin Med Insights Ther 5: 33-52.
Terpos E, Fragiadaki K, Konsta M, Bratengeier C, Papatheodorou A, Sfikakis PP. 2011. Early effects of IL-6 receptor inhibition on bone homeostasis: A pilot study in women with rheumatoid arthritis. Clin Exp Rheumatol 29: 921 925.

Uehata T, Iwasaki H, Vandenbon A, Matsushita K, Hernandez-Cuellar E, Kuniyoshi K, Satoh T, Mino T, Suzuki Y, Standley DM, et al. 2013. Malt1-induced cleavage of regnase- 1 in $\mathrm{CD}^{+}$helper $\mathrm{T}$ cells regulates immune activation. Cell 153: 1036-1049.

Vogel CFA, Goth SR, Dong B, Pessah IN, Natsumura F. 2008. Aryl hydrocarbon receptor signaling mediates expression of indoleamine 2,3-dioxygenase. Biochem Biophys Res Commun 375: 331-335.

Xu Z, Xiao SB, Xu P, Xie Q, Cao L, Wang D, Luo R, Zhong Y, Chen HC, Fang LR. 2011. MiR-365, a novel negative regulator of interleukin-6 gene expression, is cooperatively regulated by Sp1 and NF-кB. J Biol Chem 286: 21401-21412.

Yamasaki K, Taga T, Hirata Y, Yawata H, Kawanishi Y, Seed B, Taniguchi T, Hirano T, Kishimoto T. 1988. Cloning and expression of the human interleukin-6 (BSF-2/IFN- $\beta 2$ ) receptor. Science 241: 825-828.

Yang XO, Pappu BP, Nurieva R, Akimzhanov A, Kang HS, Chung Y, Ma L, Shah B, Panopoulos AD, Schluns KS, et al. 2008. T helper 17 lineage differentiation is programmed by orphan nuclear receptors $\mathrm{ROR} \alpha$ and ROR $\gamma$. Immunity 28: 29-39.

Yokota S, Imagawa T, Mori M, Miyamae T, Aihara Y, Takei S, Iwata N, Umebayashi H, Murata T, Miyoshi M, et al. 2008. Efficacy and safety of tocilizumab in patients with systemic-onset juvenile idiopathic arthritis: A randomised, double-blind, placebo-controlled, withdrawal phase III trial. Lancet 371: 998-1006.

Yokota S, Tanaka T, Kishimoto T. 2012. Efficacy, safety and tolerability of tocilizumab in patients with systemic juvenile idiopathic arthritis. Ther Adv Musculoskelet Dis 4: 387-397.

Yoshizaki K, Matsuda T, Nishimoto N, Kuritani T, Taeho L, Aozasa K, Nakahata T, Kawai H, Tagoh H, Komori T, et al. 1989. Pathogenic significance of interleukin-6 (IL-6/ BSF-2) in Castleman's disease. Blood 74: 1360-1367.

Yu D, Rao S, Tsai LM, Lee SK, He Y, Sutcliffe EL, Srivastava M, Linterman M, Zheng L, Simpson N, et al. 2009. The transcriptional repressor $\mathrm{Bcl}-6$ directs $\mathrm{T}$ follicular cell lineage commitment. Immunity 31: 457-468.

Zhang Q, Raoof M, Chen Y, Sumi Y, Sursal T, Junger W, Brohi K, Itagaki K, Hauser CJ. 2010. Circulating mitochondrial DAMPs cause inflammatory responses to injury. Nature 464: 104-107.

Zhao W, Liu M, Kirkwood KL. 2008. pp38 $\alpha$ stabilizes interleukin-6 mRNA via multiple AU-rich elements. J Biol Chem 283: 1778-1785.

Zilahi E, Tarr T, Papp G, Griger Z, Sipka S, Zeher M. 2012. Increased microRNA-146a/b, TRAF6 gene and decreased IRAK1 gene expressions in the peripheral mononuclear cells of patients with Sjögren's syndrome. Immunol Lett 141: $165-168$. 


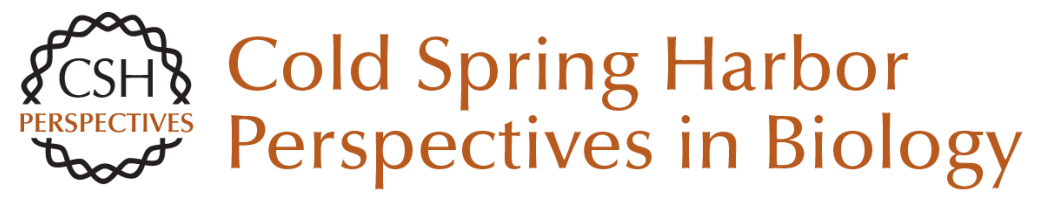

\section{IL-6 in Inflammation, Immunity, and Disease}

Toshio Tanaka, Masashi Narazaki and Tadamitsu Kishimoto

Cold Spring Harb Perspect Biol 2014; doi: 10.1101/cshperspect.a016295 originally published online September 4, 2014

Subject Collection Innate Immunity and Inflammation

Group 2 Innate Lymphoid Cells in Health and Disease

Brian S. Kim and David Artis

Inflammation and the Blood Microvascular

System

Jordan S. Pober and William C. Sessa

Sinusoidal Immunity: Macrophages at the

Lymphohematopoietic Interface

Siamon Gordon, Annette Plüddemann and

Subhankar Mukhopadhyay

Allergic Inflammation--Innately Homeostatic Laurence E. Cheng and Richard M. Locksley

Approaching the Next Revolution? Evolutionary Integration of Neural and Immune Pathogen

Sensing and Response

Kevin J. Tracey

Inflammasomes

Marcel R. de Zoete, Noah W. Palm, Shu Zhu, et al.

IL-6 in Inflammation, Immunity, and Disease

Toshio Tanaka, Masashi Narazaki and Tadamitsu Kishimoto
The Chemokine System in Innate Immunity Caroline L. Sokol and Andrew D. Luster

Microbial Sensing by Toll-Like Receptors and Intracellular Nucleic Acid Sensors Surya Pandey, Taro Kawai and Shizuo Akira

Tumor Necrosis Factor Superfamily in Innate Immunity and Inflammation John Sedý, Vasileios Bekiaris and Carl F. Ware

\section{Emerging Principles Governing Signal}

Transduction by Pattern-Recognition Receptors Jonathan C. Kagan and Gregory M. Barton

Lipid Mediators in the Resolution of Inflammation Charles N. Serhan, Nan Chiang, Jesmond Dalli, et al.

Transcriptional Control of Inflammatory

Responses

Stephen T. Smale and Gioacchino Natoli

DNA Degradation and Its Defects

Kohki Kawane, Kou Motani and Shigekazu Nagata

For additional articles in this collection, see http://cshperspectives.cshlp.org/cgi/collection/

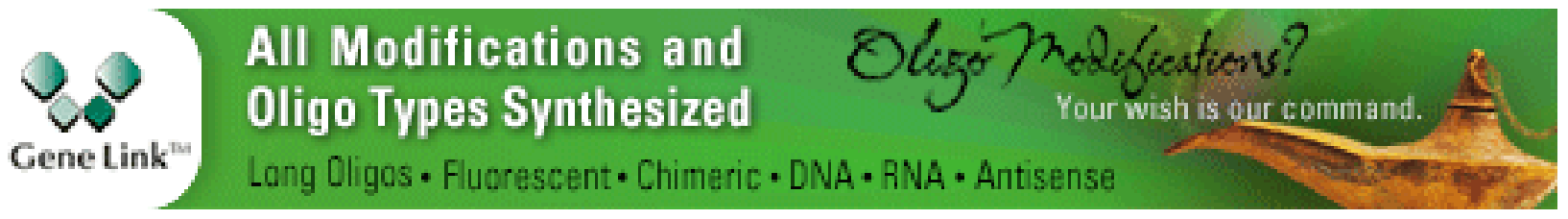

Copyright @ 2014 Cold Spring Harbor Laboratory Press; all rights reserved 